\title{
Newcastle disease virus induces testicular damage and disrupts steroidogenesis in specific pathogen free roosters
}

\author{
Zaib Ur Rehman ${ }^{1,2}$, Shanhui Ren ${ }^{1}$, Bin Yang ${ }^{1}$, Xiaofeng Yang ${ }^{1}$, Salman Latif Butt ${ }^{3}$, Alia Afzal ${ }^{4}$, \\ Muhammad Irfan Malik', Yingjie Sun ${ }^{1}$, Shengqing Yu ${ }^{1}$, Chunchun Meng ${ }^{1,5^{*}}$ and Chan Ding ${ }^{1,5^{*}}$ (])
}

\begin{abstract}
Newcastle disease (ND), which is caused by Newcastle disease virus (NDV), can cause heavy economic losses to the poultry industry worldwide. It is characterised by extensive pathologies of the digestive, respiratory, and nervous systems and can cause severe damage to the reproductive system of egg-laying hens. However, it is unknown whether NDV replicates in the male reproductive system of chickens and induces any pathologies. In this study, we selected a representative strain (i.e. ZJ1) of the most common genotype (i.e. VII) of NDV to investigate whether NDV can induce histological, hormonal, and inflammatory responses in the testes of specific pathogen free (SPF) roosters. NDV infection increased the expression of toll like receptor TLR3, TLR7, MDA5, IFN- $\alpha$, IFN- $\beta$, IFN- $\gamma$, IL-8, and CXCLi1 in the testes of NDV-infected roosters at 5 days post-infection (dpi). Severe histological changes, including decrease in the number of Sertoli cells and individualized, shrunken spermatogonia with pyknotic nuclei, were observed at $3 \mathrm{dpi}$. At $5 \mathrm{dpi}$, the spermatogenic columns were disorganized, and there were fewer cells, which were replaced by necrotic cells, lipid vacuoles, and proteinaceous homogenous material. A significant decrease in the plasma concentrations of testosterone and luteinizing hormone (LH) and the mRNA expression of their receptors in the testes, steroidogenic acute regulatory protein, cytochrome P450 side-chain cleavage enzyme, and 3 $\beta$-hydroxysteroid dehydrogenase in the NDVinfected group was observed relative to those in the control group $(P<0.05)$. Collectively, these results indicate that NDV infection induces a severe inflammatory response and histological changes, which decrease the steroidogenesis.
\end{abstract}

\section{Introduction}

Newcastle disease (ND) is caused by Avian orthoavulavirus 1 (AOAV 1) (formerly designated as Avian avulavirus 1 (AAvV-1)), commonly known as Avian paramyxovirus 1 (APMV-1), or Newcastle disease virus (NDV), and is a leading cause of economic losses to the poultry industry worldwide $[1,2]$. APMV-1 belongs to the genus Avulavirus in the family Paramyxoviridae and order Mononegavirales, which encompasses a diverse group of non-segmented, single-stranded, and negative-sense

\footnotetext{
*Correspondence: mengcc@shvri.ac.cn; shoveldeen@shvri.ac.cn

1 Shanghai Veterinary Research Institute (SHVRI), Chinese Academy of Agricultural Sciences (CAAS), Shanghai 200241, China

Full list of author information is available at the end of the article
}

RNA viruses [1, 3]. The $15 \mathrm{~kb}$ genome of NDV encodes six proteins, including the nucleocapsid, phosphoprotein, matrix $(M)$, fusion, haemagglutinin-neuraminidase, and large polymerase, and uses host cellular machinery for translation after invasion.

NDV can infect almost every species of bird, and the virulent strains of NDV cause one of the most serious infectious diseases of commercial poultry [4]. Based on the clinical manifestations, NDV is divided into four pathotypes, which are listed as follows in increasing order of virulence: asymptomatic enteric, lentogenic, mesogenic, and velogenic [5, 6]. Based on tissue tropism, velogenic strains of NDV can be further divided into viscerotropic and neurotropic strains. NDV

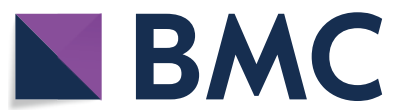

(c) The Author(s) 2020. This article is licensed under a Creative Commons Attribution 4.0 International License, which permits use, sharing, adaptation, distribution and reproduction in any medium or format, as long as you give appropriate credit to the original author(s) and the source, provide a link to the Creative Commons licence, and indicate if changes were made. The images or other third party material in this article are included in the article's Creative Commons licence, unless indicated otherwise in a credit line to the material. If material is not included in the article's Creative Commons licence and your intended use is not permitted by statutory regulation or exceeds the permitted use, you will need to obtain permission directly from the copyright holder. To view a copy of this licence, visit http://creativeco mmons.org/licenses/by/4.0/. The Creative Commons Public Domain Dedication waiver (http://creativecommons.org/publicdomain/ zero/1.0/) applies to the data made available in this article, unless otherwise stated in a credit line to the data. 
replicates in almost every organ and mainly affects the digestive, respiratory, and nervous systems and causes complex pathologies in these organs, which decrease growth and egg production.

In commercial poultry farming, broiler and layer breeders are reared to produce fertile eggs to obtain the broiler and layer chicks, which are eventually grown to meet the requirement of high-quality animal protein for human consumption. Many factors affect the fertility of roosters and hens. In roosters, semen production and quality is affected by infectious and non-infectious factors [7]. Infectious factors, such as avian leukosis virus [8], Marek's disease virus [9], and NDV [10], affect reproductive performance. Although, NDV replicates in the ovary and oviduct [11], causing severe inflammation and apoptosis, and result into decreased egg production [12-14] and fertility rates [15], the pathologic effects of NDV on the male reproductive system are yet to be characterized.

Spermatogenesis (sperm production) is a complex, hormone-controlled process, and sperm cells are produced from the spermatogonial stem cells within the seminiferous epithelium. Spermatogenesis is meticulously managed by testosterone, follicle stimulating hormone $(\mathrm{FSH})$, gonadotropin-releasing hormone $(\mathrm{GnRH})$, luteinizing hormone $(\mathrm{LH})$, germ cells, neurons within the central nervous system, and their interaction with Sertoli cells [16] and is ultimately controlled by the hypothalamus-pituitary-gonadal axis [17].

The innate immune response is the first line of defence against invading viruses and stimulates a specific mucosal and humoral immune response [18]. In NDV infection, after the detection of viruses by pattern recognition receptors (PRRs), complex host-pathogen interaction pathways direct an intense inflammatory response to inhibit viral replication $[14,19]$ and elevate plasma glucocorticoids [20]. These pro-inflammatory cytokines and their crosstalk with hormones shape the immune system to control the potential harmful effects and the return of homeostasis after the clearance of a pathogen [21, 22]. Similarly, glucocorticoids affect the hypothalamic-pituitary-gonadal axis to control the hypothalamus to synthesise and release gonadotropin releasing hormone and the pituitary gland to prevent the synthesis and release of LH, and FSH [23].

In poultry, studies of NDV pathogenesis have mainly focused on the intestines, lungs, trachea, brain, spleen and feathers [14, 24-29]. Studies on the effects of NDV infection on histological lesions, innate immune responses, and steroidogenesis in the testes are rare. Therefore, we harnessed the NDV infection in white leghorn rooster testes in this study.

\section{Materials and methods}

\section{Virus and reagents}

A wild-type velogenic NDV isolate, ZJ1, was originally isolated from geese in 2000 (Goose/China/ZJ1/2000; GB AF431744.3) and was generously provided by Professor Xiufan Liu from Yangzhou University (Yangzhou, China). The pathogenicity indices including the mean death time (MDT), intracerebral pathogenicity index (ICPI), and intravenous pathogenicity index (IVPI) of ZJ1 were 51.6, 1.89, and 2.7, respectively. ZJ1 belongs to subgenotype VIId of genotype VII, and has been responsible for the recent disease outbreaks in Asian countries [30]. The virus stock was prepared by growing the virus in 10-day-old SPF embryonating chicken eggs and was subsequently stored at $-80^{\circ} \mathrm{C}$ until further use.

\section{Animals, ethics statement and treatments}

All the animal experimental procedures were performed in strict accordance with the recommendations in the Guide for the Care and Use of Laboratory Animals of the Shanghai Veterinary Research Institute (SHVRI, Shanghai, China) of the Chinese Academy of Agricultural Sciences (CAAS, Beijing, China). All the protocols applied in this study were approved by the Institutional Animal Care and Use Committee of SHVRI (Permission number: SHVI-RO-2018030178), CAAS. All efforts were made to minimize the suffering of birds.

SPF white leghorn roosters were purchased from Zhejiang Lihua Agricultural Technology Co. Ltd (China) and reared up to the age of 25 weeks before the collection of blood samples or the challenge studies. Birds were housed in positive pressure isolators, and a photoperiod of 16L:8D was set. All the birds were provided with ad libitum access to feed and water throughout the experiment. At the age of 25 weeks, roosters were randomly divided into two groups of 20 chickens each. The birds in group 1 were mock infected with PBS and served as negative controls, whereas the birds in group 2 (NDVchallenged) were infected with $0.1 \mathrm{~mL}$ of a ZJ1 suspension containing a $10^{5.5} 50 \%$ embryo infectious dose via the right eye and choanal slit instillation.

Four birds per treatment were selected for daily blood and tissue sample collection. Blood samples were collected from the wing vein at 1,3 , and 5 days postinfection (dpi) in EDTA coated tubes and immediately transferred to the laboratory, maintaining the cold chain. To obtain the plasma, blood samples were centrifuged at $2000 \times g$ for $10 \mathrm{~min}$ at $4{ }^{\circ} \mathrm{C}$ and stored at $-80{ }^{\circ} \mathrm{C}$ until analysis. A total of four chickens per experimental treatment were sacrificed every day for the collection of testes at 1,3 , and 5 dpi. One part of every tissue sample was rinsed with PBS and put in microtubes (already marked 
and weighed), immediately frozen in liquid nitrogen, and subsequently stored at $-80^{\circ} \mathrm{C}$ until further use. Another part of each testis was fixed in $10 \%$ neutral-buffered formalin tubes for histological studies.

\section{Detection of viral loads in the testis}

The NDV ZJ1 strain was grown in 10-day-old SPF embryonated eggs and allantoic fluid was collected after $60 \mathrm{~h}$ of infection. Viral RNA was extracted from the allantoic fluid using TRIzol reagent (Invitrogen, Carlsbad, CA, USA) as per manufacturer's instructions. A 1095 bp fragment of the ZJ1 M gene was amplified, and electrophoresis was performed to know the correct size of the product. The PCR product was purified with the HiPure Gel Pure DNA Mini Kit (AnGen Biotech, Guangzhou, China) as per manufacturer's instructions and cloned into a plasmid vector to construct a standard curve. Approximately, a total of $1 \mu \mathrm{g}$ RNA extracted from the testis samples was reverse transcribed to cDNA with HiScript II (Catalogue \# R233; Vazyme Biotech Co., Ltd., China), and quantitative PCR for NDV was performed with SYBR Premix (Dongsheng, Biotech, China). Virus copy numbers were calculated using the standard curve.

\section{Histology of testis}

Tissue samples collected at 3 and 5 dpi were fixed in $10 \%$ neutral buffered formalin, processed by a standard histological procedure. Sections with a thickness of $5 \mu \mathrm{m}$ were cut and stained with haematoxylin and eosin [31]. The slides were scanned and digitalized with Panoramic SCAN (3DHISTECH Ltd., Hungary), and histopathological lesions were evaluated with CaseViewer 2.2 (3DHISTECH Ltd.).

\section{Hormone analysis}

Specific radioimmunoassay kits were used to determine plasma hormone concentrations. All samples were analysed in 1 assay to avoid inter-assay variations. Pre-experimental evaluations were conducted for all hormones to measure the optimum dilution of plasma to determine their concentration. The concentrations of testosterone (CSB-E12797C) were determined using commercially available chicken specific kits (CUSABIO, Wuhan, China) following the manufacturer protocols. The plasma $\mathrm{LH}$ levels of roosters were determined using an ELISA kit (MBS008505; MyBioSource, San Diego, CA, USA) according to the manufacturer's protocol. The minimum detectable limit of LH was less than $1.0 \mathrm{mIU} / \mathrm{mL}$. The absorbance was determined at $450 \mathrm{~nm}$ using an Epoch microplate spectrophotometer (BioTek Instruments, Inc., Winooski, VT, USA). The concentrations of testosterone and $\mathrm{LH}$ were calculated by the equation developed from the values of standards provided with the respective kits.
RNA isolation, reverse transcription, and relative gene expression/quantitative real time PCR

Quantitative RT-PCR (qRT-PCR) was performed to determine the mRNA expression levels of selected genes. Chicken GAPDH gene was used as endogenous control. The primers used in the present study are described in Table 1.

Total RNA was extracted from the frozen tissue samples using TRIzol reagent (Invitrogen, Carlsbad, CA, USA) following the manufacturer's protocol. The quality and purity of the extracted RNA were examined spectrophotometrically (NanoDrop spectrophotometer Thermo Fisher Scientific, Waltham, MA, USA) by determining the ratio of absorbance at 260 to $280 \mathrm{~nm}$. Samples with a $260 / 280$ ratio of $1.8-2.0$ were selected for reverse transcription. Purified RNA was dissolved in RNase-free water and immediately used as templates in reverse transcription. Briefly, $1 \mu \mathrm{g}$ of total RNA was mixed with $2 \mu \mathrm{L}$ gDNA wiper Mix and $0.5 \mu \mathrm{L}$ of random hexamers, and the total reaction volume was brought to $8 \mu \mathrm{L}$ by adding RNase free $\mathrm{dd}_{2} \mathrm{O}$. The mixture was heated at $42{ }^{\circ} \mathrm{C}$ for $2 \mathrm{~min}$ and then transcribed to cDNA with HiScript II (Catalogue \# R233; Vazyme Biotech Co., Ltd. China) at $55{ }^{\circ} \mathrm{C}$ for $15 \mathrm{~min}$ and $85{ }^{\circ} \mathrm{C}$ for $2 \mathrm{~min}$. The prepared cDNA samples were stored at $-25^{\circ} \mathrm{C}$ until analysis.

Real-time qRT-PCR was performed using SYBR Premix (Dongsheng Biotech, Guangzhou, China) and a CFX96 Touch Real-Time PCR Detection System (BioRad, USA). A final volume of $20 \mu \mathrm{L}$ was used for qRTPCR. The PCR cycles were as follows: $94{ }^{\circ} \mathrm{C}$ for $3 \mathrm{~min}$, followed by 40 cycles of $95{ }^{\circ} \mathrm{C}$ for $15 \mathrm{~s}, 60{ }^{\circ} \mathrm{C}$ for $15 \mathrm{~s}$, and $72{ }^{\circ} \mathrm{C}$ for $20 \mathrm{~s}$. The melting temperature of the final double-strand DNA product was determined by intercalated SYBR Green at the end of the reaction. PCR efficiencies were above 1.85 , and amplifications generated single expected amplicons with single, sharp fusion curves. All experiments were performed in triplicate. The changes in mRNA levels were presented as fold expression and calculated using the $2^{-\Delta \Delta \mathrm{CT}}$ method [32].

\section{Statistical analysis}

The data was analysed by a two-way ANOVA with challenge and time points as the main effects [33], and Graph Pad Prism 6.0 software (GraphPad Software, Inc., CA, USA) was used to generate the graphs. The graphical results were expressed as mean \pm standard deviation. Results with $P<0.05$ were considered statistically significant. When a significant main effect was observed, the Tukey test was used to compare the differences among groups. 
Table 1 Primer sequences used for quantitative PCR

\begin{tabular}{|c|c|c|c|c|}
\hline Gene type & Forward primer $\left(5^{\prime}-3^{\prime}\right)$ & Reverse primer $\left(5^{\prime}-3^{\prime}\right)$ & $\begin{array}{l}\text { Amplicon } \\
\text { size (bp) }\end{array}$ & Gen Bank accession number \\
\hline ZJ1 M gene & $\begin{array}{l}\text { ATGGACTCATCCAGGACAATC } \\
\text { GGGCT }\end{array}$ & $\begin{array}{l}\text { TTATTTCCTGAAAGGATTGTATTT } \\
\text { AGCAATGG }\end{array}$ & 1095 & AF431744.3 \\
\hline ZJ1 M gene & TACTTTGATTCTGCCCTCCCTT & TAAGCAGAGCATTGCGGAAGA & 255 & AF431744.3 \\
\hline CXCLi2/IL-8 & CATCATGAAGCATTCCATCT & CTTCCAAGGGATCTTCATTT & 205 & NM_205498.1 \\
\hline CXCLi1 & CCGATGCCAGTGCATAGAG & CCTTGTCCAGAATTGCCTTG & 191 & NM_205018.1 \\
\hline TLR3 & ACAATGGCAGATTGTAGTCACCT & GCACAATCCTGGTTTCAGTTTAG & 189 & XM_025149682.1 \\
\hline TLR7 & TGTGATGTGGAAGCCTTTGA & ATTATCTTTGGGCCCCAGTC & 219 & XM_015273651.2 \\
\hline MDA-5 & GGACGACCACGATCTCTGTGT & CACCTGTCTGGTCTGCATGTTATC & 79 & NM_001193638.1 \\
\hline IFN-a & GGAGTTTTGAGGAGGGTGGG & CGCGTCTTCCTTCCTCCTTT & 175 & XM_004937092.3 \\
\hline IFN- $\beta$ & AACACTGGATTGACCGCACA & GTCCCAGGTACAAGCACTGT & 200 & NM_001024836.1 \\
\hline IFN- $\gamma$ & TGAGCCAGATTGTTTCGATG & CTTGGCCAGGTCCATGATA & 152 & NM_205149.1 \\
\hline Androgen receptor (AR) & AGTGCCAGCCCATCTTTCTC & CCTTTGCCCACTTGACGAC & 159 & NM_001040090.1 \\
\hline LH receptor (LHR) & ACTCCTGCGCAAACCCATTC & CTCGGCTCTTACAGCAACCT & 99 & NM_204936.1 \\
\hline StAR & TTCAGCGAGATGGAGATGTCC & GGAACACCTTACCCACGTCC & 160 & NM_204686.2 \\
\hline $\begin{array}{l}\text { 3b-hydroxysteroid dehydroge- } \\
\text { nase (3ßHSD) }\end{array}$ & GGGCAAGACTGAGGTGAAAATC & TGTGTGGATGACGAGCGAG & 94 & XM_015294370.2 \\
\hline $\begin{array}{l}\text { Gallus gallus hydroxysteroid } \\
\text { 17-beta dehydrogenase } 4 \\
\text { (17ßHSD4) }\end{array}$ & CGCTGGAGGAGGTTTGGG & TGGGTACTGCTTTCCCTCCA & 167 & NM_204943.1 \\
\hline $\begin{array}{l}\text { Cholesterol side-chain cleavage } \\
\text { enzyme, P450scc }\end{array}$ & GTTGGGTGTCTACGAGAGCG & TTGCGGTAGTCACGGTATGC & 126 & NM_001001756 \\
\hline$\beta$-actin & GGTCATCACCATTGGCAATG & CCCAAGAAAGATGGCTGGAA & 66 & L08165 \\
\hline GAPDH & CCATCACAGCCACACAGAAGAC & TGGACGCTGGGATGATGTT & 93 & NM_204305 \\
\hline
\end{tabular}

\section{Results}

\section{Histopathological findings}

The normal progression of spermatogenesis involves the formation of mature spermatids (yellow arrows pointing various stages) with few attached to Sertoli cells, and few mature spermatids were present in the lumen of seminiferous tubules of the control birds. These were admixed with scant proteinaceous matrix substance and few sloughed cells in the lumen in control roosters at 3 and $5 \mathrm{dpi}$ (Figures $1 \mathrm{~A}$ and $\mathrm{C}$ ). The seminiferous tubules were separated by fine fibrovascular stroma.

At $3 \mathrm{dpi}$, the main microscopic lesions in roosters consisted of multifocal, individual spermatogonia at the basal layers of the seminiferous tubules, individualized and shrunken with pyknotic nuclei (blue arrow heads; Figure 1B). Numerous spermatogenic columns were disorganized and shortened with numerous necrotic cells filling the lumen admixed with scant spermatids. The number of Sertoli cells decreased, and there were fewer attached, late stage spermatids.

The histological study of rooster testes at $5 \mathrm{dpi}$ (Figure 1D) indicated multifocal, disorganized, and segmented spermatogenic columns, and there were fewer cells, which were replaced by necrotic cells (brown arrow heads), lipid vacuoles, and proteinaceous homogenous material. Sertoli cells were rare, and few spermatids were present in the lumen. In most severely affected tubules, only a single layer of spermatogonia remained in the basal layer. The interstitium mildly expanded with oedema. Few multinucleated cells were observed in the lumen, and few of them were necrotic (Figure 1D).

\section{Quantification of viral RNA}

Virus titres were determined by isolation of RNA from the testicular tissue. Chicken embryos did not die after inoculation of tissue homogenates from the control birds. However, all the embryos died after inoculation of eggs with testes homogenates of NDV-infected birds at $5 \mathrm{dpi}$. Viral RNA expression was analysed by qRT-PCR. There was a significant increase in the level of NDV $M$ gene expression at $5 \mathrm{dpi}$. There were approximately 15,000 copies at $5 \mathrm{dpi}$ compared to the control group (Figure 2).

\section{Effect of NDV on the sex hormones and receptors}

The plasma concentration of testosterone significantly $(P<0.05)$ decreased in the NDV-infected roosters compared to the control group at 1,3 , and 5 dpi (Figure 3). There was a non-significant interaction between the infection and dpi for testosterone. A decrease in the plasma concentrations of $\mathrm{LH}$ was observed in the 


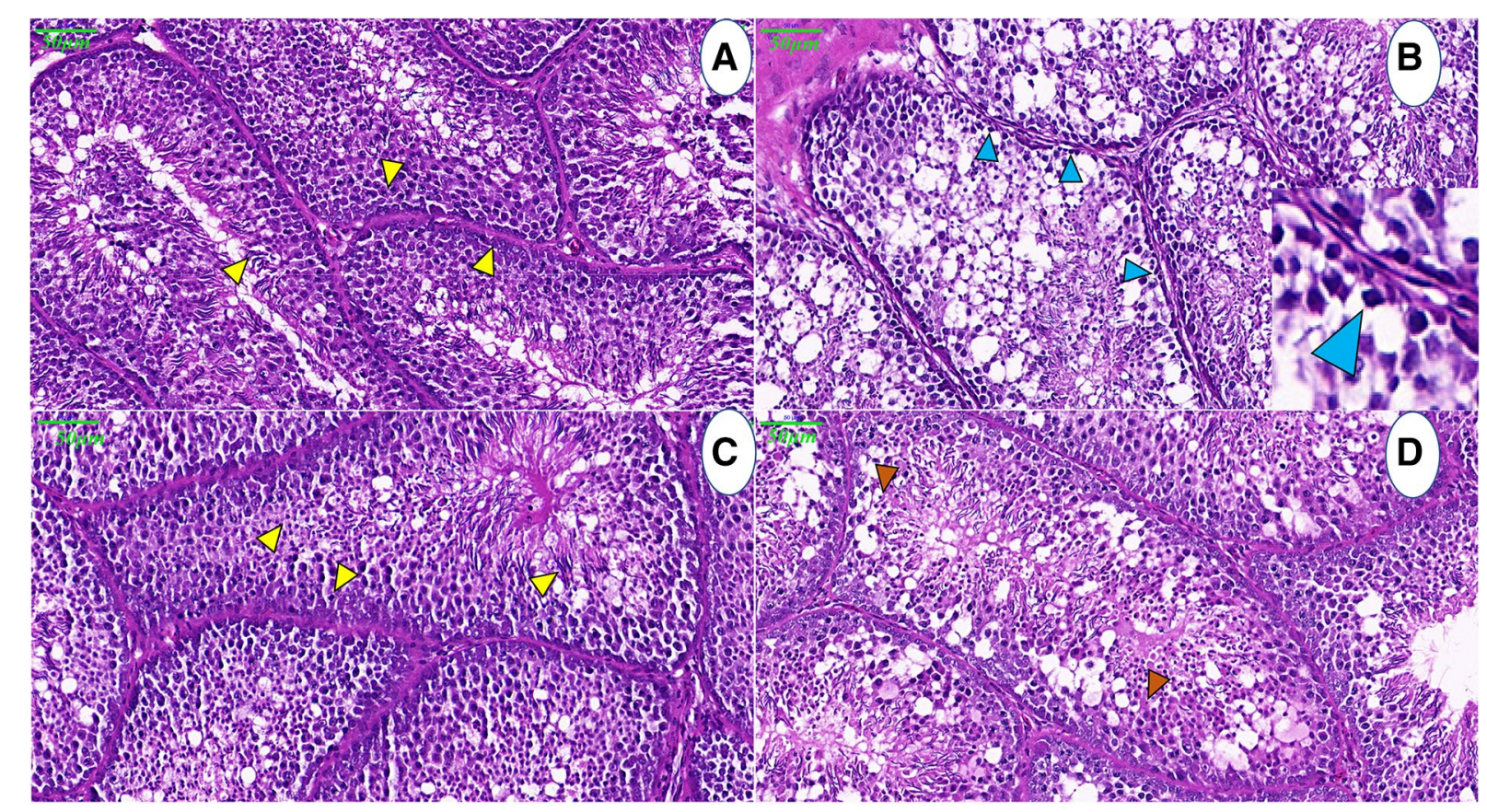

Figure 1 Photomicrograph of NDV induced histopathological changes in the testis of control and NDV infected white leghorn roosters. Normal progression of spermatogenesis (yellow arrows pointing various stages), with the formation of mature spermatids, few are attached with Sertoli cells, and small numbers of mature spermatids were present in the lumen of seminiferous tubules of control birds, at 3 and $5 \mathrm{dpi}$ (A and $\mathbf{C}$ ). Panel $\mathbf{B}$ illustrates the shortening of the adluminal compartment of seminiferous epithelium, decrease in number of Sertoli cells, individualized, shrunken spermatogonia with pyknotic nuclei (blue arrow heads), at $3 \mathrm{dpi}$. The inset shows individualised spermatogonia. Histology of testis at $5 \mathrm{dpi}$, denotes multifocal, and segmented, spermatogenic columns, necrotic cells (brown arrow heads), lipid vacuoles and proteinaceous homogenous material. Sertoli cells were rare and small numbers of spermatids were present in the lumen (D).

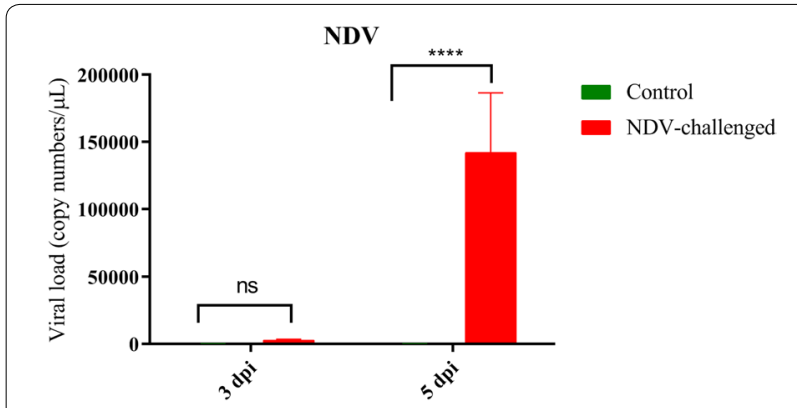

Figure 2 Relative quantity of Viral RNA in the testis of roosters. Graphs are denoted as mean \pm standard deviation. The data were analysed by two-way ANOVA test, with challenge and time points as the main effects.

NDV-infected birds, but these levels were only statistically significant at 3 and 5 dpi (Figure 3 ). The plasma $\mathrm{LH}$ concentrations decreased in the NDV-infected birds compared to the control birds, particularly at 3 and $5 \mathrm{dpi}$. The interaction effects of dpi and NDV infection were non-significant.

The relative mRNA expression levels of the androgen receptor (AR) and $\mathrm{LH}$ receptor (LHR) in the testicular tissue are shown in Figure 3. The mRNA expression levels of AR were significantly $(P<0.05)$ decreased in the testicular tissue of the NDV-infected birds, but this decrease was more pronounced at $5 \mathrm{dpi}$. LHR expression in the control birds was significantly $(P<0.05)$ higher than that in the-NDV infected birds (Figure 3).

\section{Effect of NDV infection on mRNA expression of steroidogenesis related protein and enzymes}

To verify the results of the plasma hormones, expression analysis of P450scc, StAR, and 33HSD was performed by qRT-PCR. NDV infection decreased the mRNA expression of P450scc in the NDV-infected group $(P<0.05)$ compared to the control group. Similarly, decreased expression of the 3ßHSD was observed in infected birds at 3 and $5 \mathrm{dpi}$, as compared to non-infected birds (Figure 4). This decrease was more pronounced at $5 \mathrm{dpi}$ than at 3 dpi. Experimental infection of roosters with NDV also decreased the expression $(P<0.05)$ of StAR in the testes compared to roosters in the control group. Although decreased expression was observed at both 3 and $5 \mathrm{dpi}$, it was lower at $5 \mathrm{dpi}$ (Figure 4). 


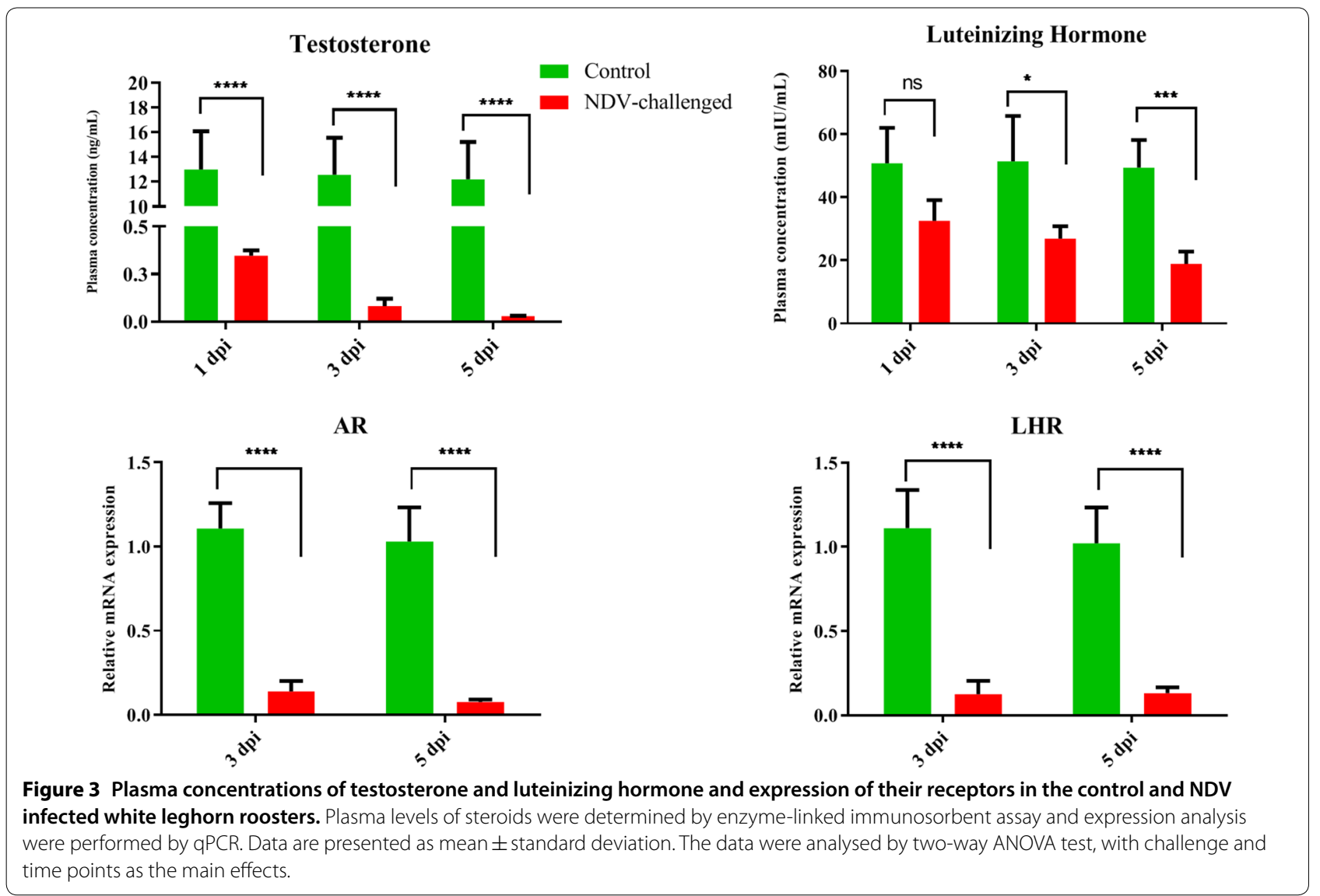

\section{NDV infection upregulated the mRNA levels of PRRs}

We compared the mRNA expression levels of PRRs, including toll-like receptor TLR 3, TLR7, and melanoma differentiation-associated protein 5 (MDA5) in the testicular tissue of NDV-infected and control birds at 3 and $5 \mathrm{dpi}$. Compared to roosters in the control group, the expression levels of TLR3 and TLR7 in the testes of NDV-infected birds were significantly upregulated at $5 \mathrm{dpi}$, but these upregulations were only significant for TLR3 at 3 dpi (Figure 5). As shown in Figure 5, MDA5 was significantly upregulated in the NDV-infected group at $3 \mathrm{dpi}$ compared to the control group. The upregulation of MDA 5 in the NDV-infected group at $5 \mathrm{dpi}$ was not significantly higher than that in the control.

\section{Differential expression of innate immune genes}

Interferons (IFNs) are the most potent innate immune molecules to control and surpass viral replication and modulate innate immune responses to protect the host from viral pathogens. Therefore, we compared the expression of IFNs, including IFN- $\alpha$, IFN- $\beta$, and IFN- $\gamma$, in the testes of roosters from the control and NDV-infected groups at 3 and $5 \mathrm{dpi}$ (Figure 6). The expression of IFN- $\alpha$,
IFN- $\beta$, and IFN- $\gamma$ was upregulated at $3 \mathrm{dpi}$, but these upregulations were only significant at $5 \mathrm{dpi}$ (Figure 6). The expression levels of IL-8, CXCLi1, and iNOS were also examined by qRT-PCR. NDV infection significantly increased the expression of IL-8 at 5 dpi. NDV infection significantly $(P<0.05)$ increased the expression of iNOS in the infected roosters. The mRNA expression levels in the testes of NDV-infected birds peaked at $5 \mathrm{dpi}$. However, the expression of CXCLi1 decreased at $3 \mathrm{dpi}$ in the testes of NDV-infected birds and increased at $5 \mathrm{dpi}$ (Figure 6).

\section{Discussion}

In the present study, we investigated the effects of NDV infection on the expression of PRRs, innate immune genes, enzymes involved in steroidogenesis, reproduction hormones levels, and histopathology of testes in SPF roosters. Many studies have attempted to explain the modulation of innate immune genes and histological structure in different organs and organ systems, including the digestive system, respiratory system, spleen, nervous system and female reproductive system [14, 24-28]. However, to the best of our knowledge, an 


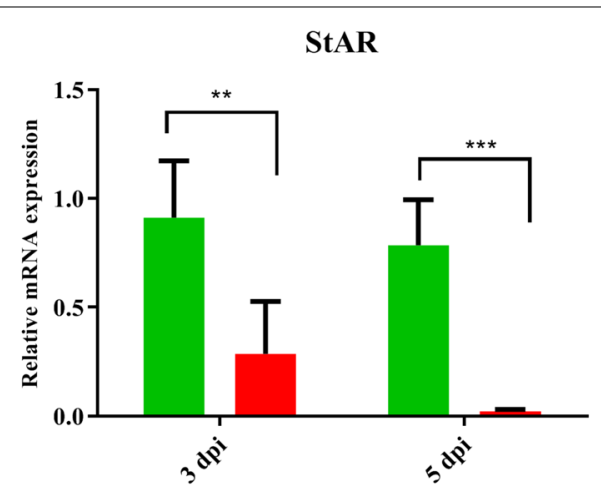

3ßHSD

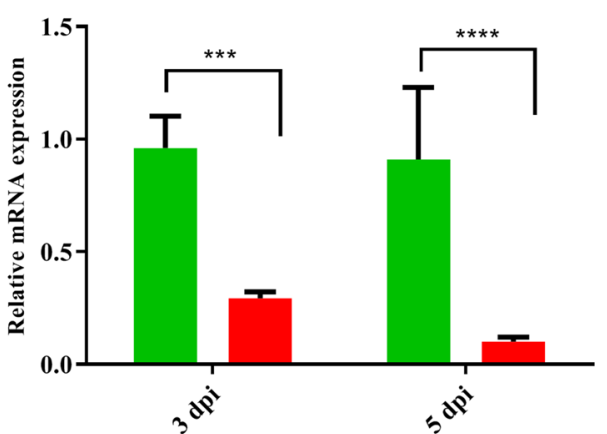

Control

NDV-challenged

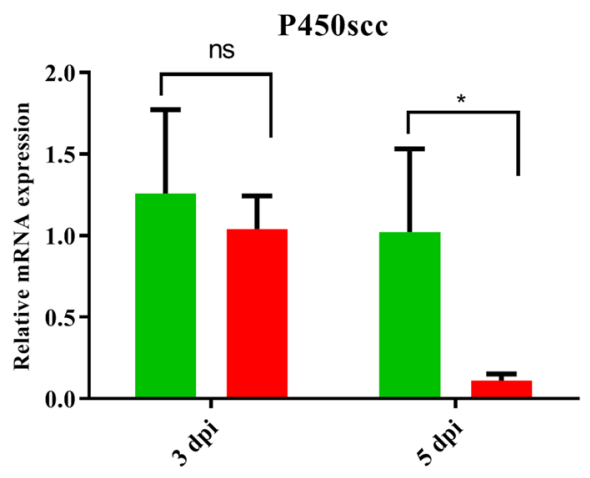

17ßHSD4

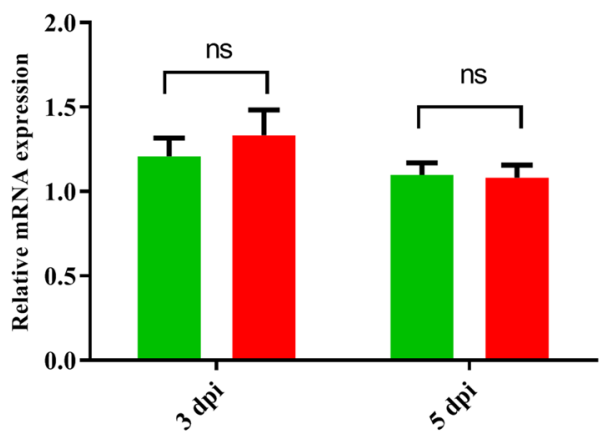

Figure 4 The effects of NDV infection on the mRNA expression of steroidogenesis related key protein StAR and enzymes P450scc, $3 \beta \mathrm{HSD}$, and $17 \beta \mathrm{HSD} 4$ in rooster testis. Data are presented as mean \pm standard deviation. The data were analysed by two-way ANOVA test, with challenge and time points as the main effects. StAR: Steroidogenic acute regulatory protein; P450scc: Cholesterol side-chain cleavage enzyme; 3ßHSD: $3 \beta$-hydroxysteroid dehydrogenase.

attempt has never been made to study the fate of NDV infection in the testes of roosters.

Innate immune responses are the first line of defence of the host against invading pathogens and play a critical role in the determination of disease. Viruses are recognized by the PRRs, including TLRs, cytosolic retinoic acid inducible gene I (RIG-I)-like receptors, and MDA5 $[34,35]$. In this study, increased expression of TLR3, TLR7, and MDA5 was noted in the testicular tissues of NDV-infected roosters. In NDV infection, upregulation of TLR3, TLR7, and MDA5 was noted in the DF-1 cells and different tissues [14, 36-39], which is in accordance with the results of the present study. Overexpression of TLR activates the MyD88-dependent pathway to produce cytokines, MHC molecules, and chemokines, leading to effective immune responses to clear invading pathogens $[40,41]$. In this study, increased expression of CXCLi1 and IL-8 was noted in the testes of NDVinfected roosters. Upregulation of CXCLi1 and IL-8 might trigger immune cells at the infection site.
IFNs are part of the arsenal of the innate immune system against viruses [42]. Increased expression of IFNs has been noted in NDV infection [14, 36, 43, 44]. IFN production stimulates neighbouring cells to increase the expression of IFN-stimulated genes, leading to an antiviral state to inhibit virus replication [45]. Increased expression levels of IFN- $\alpha$, IFN- $\beta$, and IFN- $\gamma$ were noted in the testes of NDV-infected birds in the present study.

The ratio of roosters to laying hens is low, but roosters are equally important to produce fertile eggs and the subsequent performance of chicks. Different factors, such as nutrition [46-48], age [49,50], hormones [51, 52], and infectious diseases [53-56], can affect the reproductive performance of roosters. Spermatogenesis is controlled by an array of pathways, especially by those including reproductive hormones. It takes place in the seminiferous epithelium and is controlled by the activity of Sertoli cells and their interaction with germ cells, testosterone, FSH, LH, oestradiol, and progesterone. In this study, decrease in the plasma levels of testosterone and LH in NDV-infected birds is indicative of disruptive effect of 


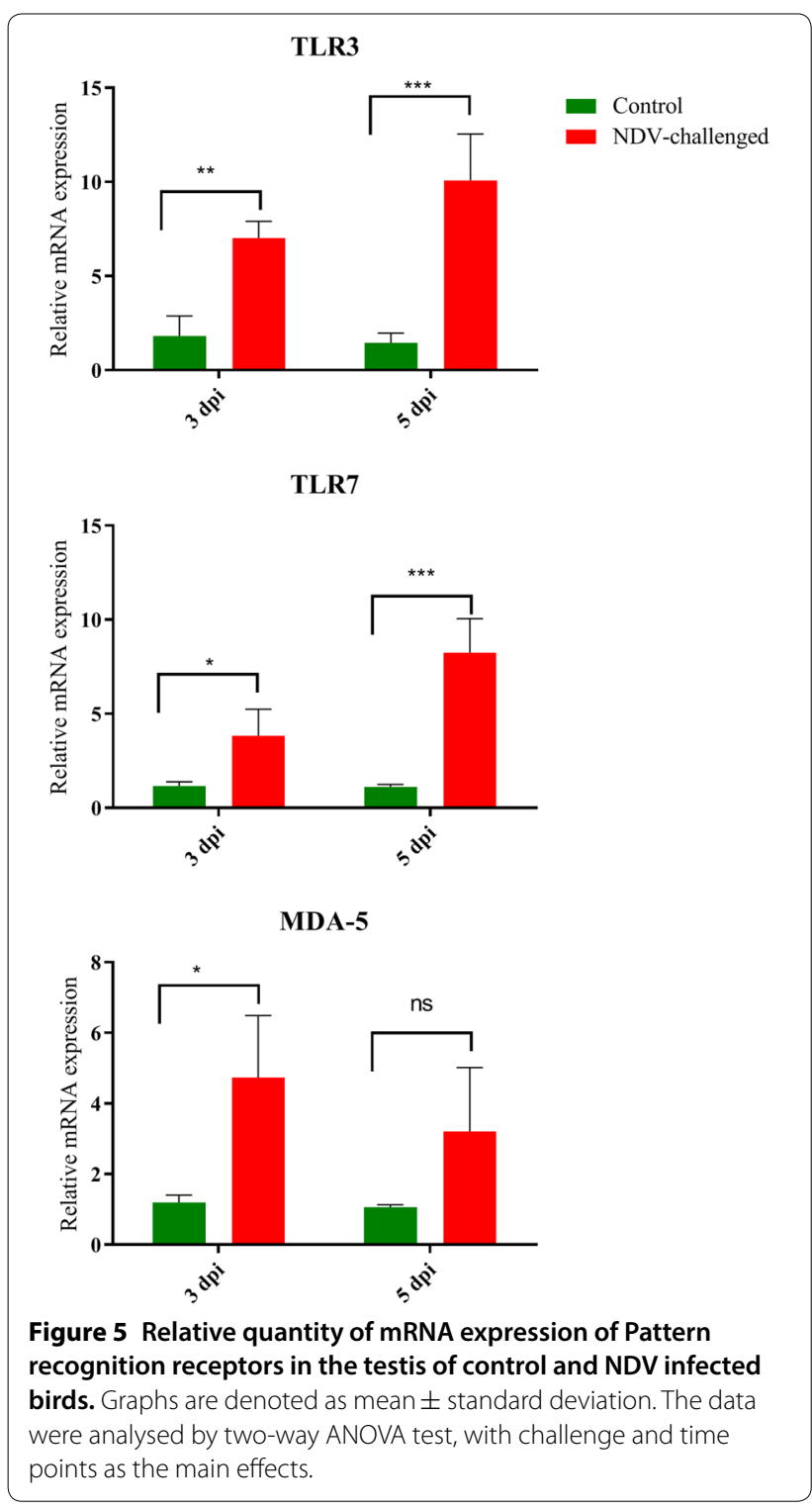

NDV on spermatogenesis. Decreased levels of testosterone have been shown to be associated with decreased fertility in roosters [52, 57].

In this study, examination of the viral load showed that NDV replicates in the testes of SPF roosters. Severe histological lesions were noted in the testes of NDV-infected roosters at $5 \mathrm{dpi}$ than at $3 \mathrm{dpi}$, which may have been due to more viral copies. The optimum level of reproductive hormones ensures the spermatogenesis, however, disorganized spermatogenic columns and fewer cells with replacement by necrotic cells, lipid vacuoles, and proteinaceous homogenous material in the infected roosters are well correlated with the viral load and lowered level of reproductive hormones. The presence of rare Sertoli cells, few spermatids in the lumen, and severely affected tubules, only a single layer of spermatogonia remained in the basal layer could be explained with the fact that testosterone and FSH levels were lowered in the NDV infected birds. These microscopic lesions may have disturbed the plasma hormone levels, as the affected cells were associated with the production of testosterone.

Testosterone is produced from cholesterol through a series of reactions catalysed by different enzymes and proteins. The key enzymes and proteins involved in the synthesis of testosterone are P450scc, 33HSD, and StAR [58]. In the Leydig cells, translocation of cholesterol from the outer to the inner mitochondrial membrane is regulated by StAR [59]. Then, conversion of cholesterol to pregnenolone is catalysed by P450scc [59]. StAR and $\mathrm{P} 450$ scc are the rate limiting factors in pregnenolone synthesis. Then, pregnenolone, a precursor for the synthesis of diverse steroids, moves to the smooth endoplasmic reticulum and is converted to dehydroepiandrosterone and then androstenedione by $3 \beta \mathrm{HSD}$. The final conversion of androstenedione to testosterone is catalysed by $17 \beta$ HSD [60]. In the current study, NDV infection significantly downregulated the expression of StAR, P450scc, and $3 \beta$ HSD. These results indicate that decreased mRNA expression of StAR, P450scc, and 3 $3 \mathrm{HSD}$ may have been the cause of decreased biosynthesis of hormones because the synthesis and levels of testosterone are closely associated with the expression of StAR, P450scc, and 3BHSD $[58,60]$. Steroid synthesis is regulated by steroidogenic factor-1 [61].

LH stringently controls steroidogenesis. In the present study, NDV infection decreased expression of LHR and $\mathrm{AR}$ and the plasma levels of $\mathrm{LH}$ and testosterone. In addition to steroidogenesis, depletion of AR in murine Leydig cells inhibits spermatogenesis in the spermatid stage, decreases plasma testosterone levels, and reduces several key steroidogenic enzymes, including $17 \beta \mathrm{HSD}, 3 \beta \mathrm{HSD}$, and P450scc [62]. Therefore, the decreased expression of steroidogenic enzymes in NDV-infected birds may have been due to decreased expression of LHR and AR.

In conclusion, our results demonstrate that NDV replicates in the testicular tissue, increases the expression of PPRs, upregulates the innate immune response, induces histological lesions, and inhibits steroidogenesis and spermatogenesis. These observations suggest that decreased plasma levels of testosterone and LH may be due to decreased expression of LHR and AR and steroidogenic enzymes in NDV-infected roosters. These findings also explain the possible reduction in the fertility and hatchability in NDV infected breeder flocks. 

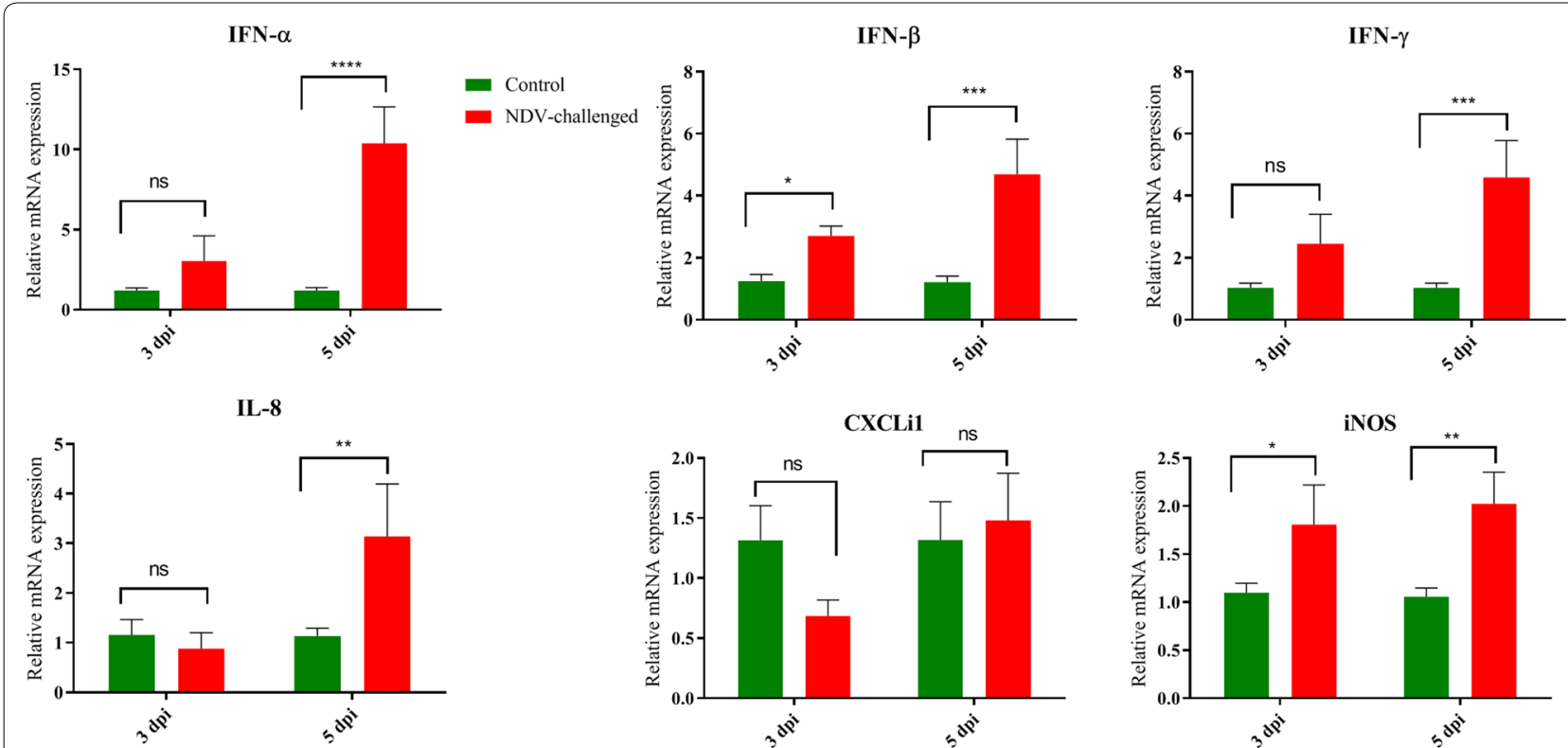

Figure 6 Relative quantity of mRNA expression of innate immune genes in the testis of control and NDV infected birds. Graphs are denoted as mean \pm standard deviation. The data were analysed by two-way ANOVA test, with challenge and time points as the main effects.

\section{Abbreviations}

ND: Newcastle disease; NDV: Newcastle disease virus; TLR: Toll like receptor; MDA5: Melanoma differentiation-associated protein 5; IFN: Interferons; IL-8: Interleukin 8; LH: Luteinizing hormone; dpi: Day post-infection; StAR: Steroidogenic acute regulatory protein; P450scc: Cytochrome P450 sidechain cleavage enzyme; 33HSD: 33-Hydroxysteroid dehydrogenase; APMV-1: Avian avulavirus 1; FSH: Follicle stimulating hormone (FSH); SHVRI: Shanghai Veterinary Research Institute (Shanghai, China); CAAS: Chinese Academy of Agricultural Sciences; CON: Control; AR: Androgen receptor; LHR: Luteinizing hormone receptor; RIG-I: Retinoic acid inducible gene I.

\section{Acknowledgements}

These authors are funded by the National Key Research and Development Program of China (No. 2018YFD0500100), National Natural Science Foundation of China (No. 31530074), and Shanghai Key Laboratory of Veterinary Biotechnology (No. klab201702). The funders had no role in study design, data collection and interpretation, or the decision to submit the work for publication.

\section{Authors' contributions}

ZUR conceived, designed, performed the experiments, and wrote the manuscript; MIM and SR helped in the animal experiments and sample collection, $B Y, X Y, C M, Y S$, and SY helped in the lab experiments; AA, SR, and ZUR, analyzed the data; SLB read and described the histological slides, and proof read the manuscript; CM and CD supervise the study, and contributed the reagents/materials/analysis tools. All authors read and approved the final manuscript.

\section{Competing interests}

The authors declare that they have no competing interests.

\section{Author details}

${ }^{1}$ Shanghai Veterinary Research Institute (SHVRI), Chinese Academy of Agricultural Sciences (CAAS), Shanghai 200241, China. ${ }^{2}$ Department of Poultry Science, Faculty of Veterinary and Animal Sciences, PMAS Arid Agriculture University, 46300 Rawalpindi, Pakistan. ${ }^{3}$ Department of Pathology, College of Veterinary Medicine, University of Georgia, Athens, GA 30602, USA. ${ }^{4}$ Institute of Statistics, Faculty of Economics and Management, Leibniz University Hannover, 30167 Hannover, Germany. ${ }^{5}$ Jiangsu Co-innovation Center for Prevention and Control of Important Animal Infectious Disease and Zoonoses, Yangzhou University, Yangzhou 225009, China.
Received: 4 November 2019 Accepted: 27 April 2020

Published online: 29 June 2020

\section{References}

1. Alexander DJ (2003) Newcastle disease. In: Saif YM, Barnes HJ, Glisson JR, Fadly AM, McDougald LR, Swayne DE (eds) Disease of poultry. lowa State Press, Ames, IA

2. Meng C, Rehman ZU, Liu K, Qiu X, Tan L, Sun Y, Liao Y, Song C, Yu S, Ding Z, Nair V, Munir M, Ding C (2018) Potential of genotype VII Newcastle disease viruses to cause differential infections in chickens and ducks. Transbound Emerg Dis 65:1851-1862

3. Rehman ZU, Che L, Ren S, Liao Y, Qiu X, Yu S, Sun Y, Tan L, Song C, Liu W, Ding Z, Munir M, Nair V, Meng C, Ding C (2018) Supplementation of vitamin E protects chickens from newcastle disease virus-mediated exacerbation of intestinal oxidative stress and tissue damage. Cell Physiol Biochem 47:1655-1666

4. Ren S, Wang C, Zhang X, Zhao L, Wang X, Yao W, Han Q, Wang Y, Fan M, Gao X, Xiao S, Wang X, Yang Z (2017) Phylogenetic and pathogenic characterization of a pigeon paramyxovirus type 1 isolate reveals crossspecies transmission and potential outbreak risks in the northwest region of China. Arch Virol 162:2755-2767

5. Moura VM, Susta L, Cardenas-Garcia S, Stanton JB, Miller PJ, Afonso CL, Brown CC (2016) Neuropathogenic capacity of lentogenic, mesogenic, and velogenic newcastle disease virus strains in day-old chickens. Vet Pathol 53:53-64

6. Rehman Z, Qiu X, Sun Y, Liao Y, Tan L, Song C, Yu S, Ding Z, Munir M, Nair V Meng C, Ding C (2018) Vitamin E supplementation ameliorates newcastle disease virus-induced oxidative stress and alleviates tissue damage in the brains of chickens. Viruses 10:173

7. Crespo R, Shivaprasad HL (2010) Decrease of fertility in a broiler breeder flock due to testicular atrophy. Avian Dis 54:142-145

8. Afanassieff M, Dambrine G, Ronfort C, Lasserre F, Coudert F, Verdier G (1996) Intratesticular inoculation of avian leukosis virus (ALV) in chickensproduction of neutralizing antibodies and lack of virus shedding into semen. Avian Dis 40:841-852

9. Pettit JR, Taylor PA, Gough AW (1976) Microscopic lesions suggestive of Marek's disease in a Black Francolin (Francolinus f. francolinus). Avian Dis 20:410-415 
10. Rwuaan JS, Rekwot PI, Abdu PA, Eduvie LO, Obidi JA (2009) Semen characteristics of vaccinated shikabrown cocks challenged with a velogenic Newcastle disease virus. Int J Poult Sci 8:896-901

11. Sa ESM, Susta L, Moresco K, Swayne DE (2016) Vaccination of chickens decreased Newcastle disease virus contamination in eggs. Avian Pathol 45:38-45

12. Raghul J, Raj GD, Manohar BM, Balachandran C (2006) Protection of the reproductive tract of young chicks by Newcastle disease virus-induced hemagglutination inhibition antibodies. Vet Res Commun 30:95-102

13. Bwala DG, Clift S, Duncan NM, Bisschop SP, Oludayo FF (2012) Determination of the distribution of lentogenic vaccine and virulent Newcastle disease virus antigen in the oviduct of SPF and commercial hen using immunohistochemistry. Res Vet Sci 93:520-528

14. Li R, Guo K, Liu C, Wang J, Tan D, Han X, Tang C, Zhang Y, Wang J (2016) Strong inflammatory responses and apoptosis in the oviducts of egglaying hens caused by genotype VIId Newcastle disease virus. BMC Vet Res 12:255

15. Alexander DJ (2000) Newcastle disease and other avian paramyxoviruses. Rev Sci Technol 19:443-462

16. Vizcarra J, Alan R, Kirby J (2015) Reproduction in male birds. In: Scanes CG (ed) Sturkie's Avian physiology, 6th edn. Academic Press, San Diego

17. Bedecarrats GY (2015) Control of the reproductive axis: balancing act between stimulatory and inhibitory inputs. Poult Sci 94:810-815

18. Rehman ZU, Meng C, Umar S, Mahrose KM, Ding C, Munir M (2019) Mast cells and innate immunity: master troupes of the avian immune system. World's Poult Sci J 73:621-632

19. Ecco R, Brown C, Susta L, Cagle C, Cornax I, Pantin-Jackwood M, Miller PJ, Afonso CL (2011) In vivo transcriptional cytokine responses and association with clinical and pathological outcomes in chickens infected with different Newcastle disease virus isolates using formalin-fixed paraffinembedded samples. Vet Immunol Immunopathol 141:221-229

20. Park J, Kim M, Na G, Jeon I, Kwon YK, Kim JH, Youn H, Koo Y (2007) Glucocorticoids modulate NF-kappaB-dependent gene expression by up-regulating FKBP51 expression in Newcastle disease virus-infected chickens. Mol Cell Endocrinol 278:7-17

21. Borghetti P, Saleri R, Mocchegiani E, Corradi A, Martelli P (2009) Infection, immunity and the neuroendocrine response. Vet Immunol Immunopathol 130:141-162

22. Borghetti P, Saleri R, Ferrari L, Morganti M, De Angelis E, Franceschi V, Bottarelli E, Martelli P (2011) Cytokine expression, glucocorticoid and growth hormone changes after porcine reproductive and respiratory syndrome virus (PRRSV-1) infection in vaccinated and unvaccinated naturally exposed pigs. Comp Immunol Microbiol Infect Dis 34:143-155

23. Whirledge S, Cidlowski JA (2010) Glucocorticoids, stress, and fertility. Minerva Endocrinol 35:109-125

24. Hussein EA, Hair-Bejo M, Omar AR, Arshad SS, Hani H, Balakrishnan KN, Yakubu Y, Saeed MI, Aini I (2019) Velogenic newcastle disease virus tissue tropism and pathogenesis of infection in chickens by application of in situ PCR, immunoperoxidase staining and HE staining. Microb Pathog 129:213-223

25. Cui N, Huang X, Kong Z, Huang Y, Huang Q, Yang S, Zhang L, Xu C, Zhang $X$, Cui $Y$ (2018) Newcastle disease virus infection interferes with the formation of intestinal microflora in newly hatched specific-pathogen-free chicks. Front Microbiol 9:900

26. Sun Y, Yu S, Ding N, Meng C, Meng S, Zhang S, Zhan Y, Qiu X, Tan L, Chen $H$, Song C, Ding C (2014) Autophagy benefits the replication of Newcastle disease virus in chicken cells and tissues. J Virol 88:525-537

27. Nakamura K, Ohtsu N, Nakamura T, Yamamoto Y, Yamada M, Mase M, Imai K (2008) Pathologic and immunohistochemical studies of Newcastle disease (ND) in broiler chickens vaccinated with ND: severe non-purulent encephalitis and necrotizing pancreatitis. Vet Pathol 45:928-933

28. Nakamura K, Ito M, Nakamura T, Yamamoto Y, Yamada M, Mase M, Imai K (2014) Pathogenesis of Newcastle disease in vaccinated chickens: pathogenicity of isolated virus and vaccine effect on challenge of its virus. J Vet Med Sci 76:31-36

29. Butt SL, Moura V, Susta L, Miller PJ, Hutcheson JM, Cardenas-Garcia S, Brown CC, West FD, Afonso CL, Stanton JB (2019) Tropism of Newcastle disease virus strains for chicken neurons, astrocytes, oligodendrocytes, and microglia. BMC Vet Res 15:317
30. Rehman ZU, Meng C, Sun Y, Mahrose KM, Umar S, Ding C, Munir M (2018) Pathobiology of Avian avulavirus 1: special focus on waterfowl. Vet Res 49:94

31. Qu Y, Zhan Y, Yang S, Ren S, Qiu X, Rehamn ZU, Tan L, Sun Y, Meng C, Song C, Yu S, Ding C (2018) Newcastle disease virus infection triggers HMGB1 release to promote the inflammatory response. Virology 525:19-31

32. Livak KJ, Schmittgen TD (2001) Analysis of relative gene expression data using real-time quantitative PCR and the 2(-Delta Delta C(T)) method. Methods 25:402-408

33. Assaad HI, Hou Y, Zhou L, Carroll RJ, Wu G (2015) Rapid publication-ready MS-Word tables for two-way ANOVA. Springerplus 4:33

34. Chen S, Cheng A, Wang M (2013) Innate sensing of viruses by pattern recognition receptors in birds. Vet Res 44:82

35. Sun Y, Mao X, Zheng H, Wu W, Rehman ZU, Liao Y, Meng C, Qiu X, Tan L, Song C, Xu L, Yu S, Ding C (2019) Goose MAVS functions in RIG-I-mediated IFN-beta signaling activation. Dev Comp Immunol 93:58-65

36. Rue CA, Susta L, Cornax I, Brown CC, Kapczynski DR, Suarez DL, King DJ, Miller PJ, Afonso CL (2011) Virulent Newcastle disease virus elicits a strong innate immune response in chickens. J Gen Virol 92:931-939

37. Susta L, Miller PJ, Afonso CL, Brown CC (2011) Clinicopathological characterization in poultry of three strains of Newcastle disease virus isolated from recent outbreaks. Vet Pathol 48:349-360

38. Kang Y, Feng M, Zhao X, Dai X, Xiang B, Gao P, Li Y, Li Y, Ren T (2016) Newcastle disease virus infection in chicken embryonic fibroblasts but not duck embryonic fibroblasts is associated with elevated host innate immune response. Virol J 13:41

39. Sun Y, Ding N, Ding SS, Yu S, Meng C, Chen H, Qiu X, Zhang S, Yu Y, Zhan Y, Ding C (2013) Goose RIG-I functions in innate immunity against Newcastle disease virus infections. Mol Immunol 53:321-327

40. Cheng J, Sun Y, Zhang X, Zhang F, Zhang S, Yu S, Qiu X, Tan L, Song C, Gao S, Wu Y, Ding C (2014) Toll-like receptor 3 inhibits Newcastle disease virus replication through activation of pro-inflammatory cytokines and the type-1 interferon pathway. Arch Virol 159:2937-2948

41. Brownlie R, Allan B (2011) Avian toll-like receptors. Cell Tissue Res 343:121-130

42. Goodbourn S, Didcock L, Randall RE (2000) Interferons: cell signalling, immune modulation, antiviral response and virus countermeasures. J Gen Virol 81:2341-2364

43. Abdolmaleki M, Yeap SK, Tan SW, Satharasinghe DA, Bello MB, Jahromi MZ, Bejo MH, Omar AR, Ideris A (2018) Effects of Newcastle disease virus infection on chicken intestinal intraepithelial natural killer cells. Front Immunol 9:1386

44. Rasoli M, Yeap SK, Tan SW, Moeini H, Ideris A, Bejo MH, Alitheen NB, Kaiser P, Omar AR (2014) Alteration in lymphocyte responses, cytokine and chemokine profiles in chickens infected with genotype VII and VIII velogenic Newcastle disease virus. Comp Immunol Microbiol Infect Dis 37:11-21

45. Krishnamurthy S, Takimoto T, Scroggs RA, Portner A (2006) Differentially regulated interferon response determines the outcome of Newcastle disease virus infection in normal and tumor cell lines. J Virol 80:5145-5155

46. Safari Asl R, Shariatmadari F, Sharafi M, Karimi Torshizi MA, Shahverdi A (2018) Improvements in semen quality, sperm fatty acids, and reproductive performance in aged Ross breeder roosters fed a diet supplemented with a moderate ratio of n-3: n-6 fatty acids. Poult Sci 97:4113-4121

47. Alhaj HW, Li Z, Shan T, Dai P, Zhu P, Li Y, Alsiddig MA, Abdelghani E, Li C (2018) Effects of dietary sodium butyrate on reproduction in adult breeder roosters. Anim Reprod Sci 196:111-119

48. Kazemizadeh A, Zare Shahneh A, Zeinoaldini S, Yousefi AR, Mehrabani Yeganeh H, Ansari Pirsaraei Z, Akhlaghi A (2019) Effects of dietary curcumin supplementation on seminal quality indices and fertility rate in broiler breeder roosters. Br Poult Sci 60:256-264

49. Avital-Cohen N, Heiblum R, Argov-Argaman N, Rosenstrauch A, Chaiseha Y, Mobarkey N, Rozenboim I (2013) Age-related changes in gonadal and serotonergic axes of broiler breeder roosters. Domest Anim Endocrinol 44:145-150

50. Lagares MA, Ecco R, Martins N, Lara L, Rocha J, Vilela D, Barbosa VM, Mantovani PF, Braga J, Preis IS, Gheller VA, Cardeal PC, Baiao NC (2017) Detecting reproductive system abnormalities of broiler breeder roosters at different ages. Reprod Domest Anim 52:67-75

51. Avital-Cohen N, Heiblum R, Argov N, Rosenstrauch A, Chaiseha Y, Mobarkey N, Rozenboim I (2012) The effect of active immunization 
against vasoactive intestinal peptide (VIP) and inhibin on reproductive performance of aging White Leghorn roosters. Poult Sci 91:161-174

52. Weil S, Rozenboim I, Degen AA, Dawson A, Friedlander M, Rosenstrauch A (1999) Fertility decline in aging roosters is related to increased testicular and plasma levels of estradiol. Gen Comp Endocrinol 115:23-28

53. Monleon R, Martin MP, John Barnes H (2008) Bacterial orchitis and epididymo-orchitis in broiler breeders. Avian Pathol 37:613-617

54. Janssen SJ, Kirby JD, Hess RA, Rhoads M, Bunick D, Bailey KL, Parsons CM Wang H, Bahr JM (2000) Identification of epididymal stones in diverse rooster populations. Poult Sci 79:568-574

55. Boltz DA, Zimmerman CR, Nakai M, Bunick D, Scherba G, Bahr JM (2006) Epididymal stone formation and decreased sperm production in roosters vaccinated with a killed strain of avian infectious bronchitis virus. Avian Dis 50:594-598

56. Boltz CR, Boltz DA, Bunick D, Scherba G, Bahr JM (2007) Vaccination against the avian infectious bronchitis virus affects sperm concentration, sperm quality and blood testosterone concentrations in cockerels. $\mathrm{Br}$ Poult Sci 48:617-624

57. Sarabia Fragoso J, Pizarro Diaz M, Abad Moreno JC, Casanovas Infesta P, Rodriguez-Bertos A, Barger K (2013) Relationships between fertility and some parameters in male broiler breeders (body and testicular weight, histology and immunohistochemistry of testes, spermatogenesis and hormonal levels). Reprod Domest Anim 48:345-352
58. Saillenfait AM, Sabate JP, Denis F, Antoine G, Robert A, Eljarrat E (2018) The pyrethroid insecticides permethrin and esfenvalerate do not disrupt testicular steroidogenesis in the rat fetus. Toxicology 410:116-124

59. Miller WL, Strauss JF (1999) Molecular pathology and mechanism of action of the steroidogenic acute regulatory protein, StAR. J Steroid Biochem Mol Biol 69:131-141

60. Heng D, Zhang T, Tian Y, Yu S, Liu W, Xu K, Liu J, Ding Y, Zhu B, Yang Y, Zhang C (2017) Effects of dietary soybean isoflavones (SI) on reproduction in the young breeder rooster. Anim Reprod Sci 177:124-131

61. Meinsohn MC, Smith OE, Bertolin K, Murphy BD (2019) The orphan nuclear receptors steroidogenic factor-1 and liver receptor homolog-1: structure, regulation, and essential roles in mammalian reproduction. Physiol Rev 99:1249-1279

62. Xu Q, Lin HY, Yeh SD, Yu IC, Wang RS, Chen YT, Zhang C, Altuwaiji S, Chen LM, Chuang KH, Chiang HS, Yeh S, Chang C (2007) Infertility with defective spermatogenesis and steroidogenesis in male mice lacking androgen receptor in Leydig cells. Endocrine 32:96-106

\section{Publisher's Note}

Springer Nature remains neutral with regard to jurisdictional claims in published maps and institutional affiliations.
Ready to submit your research? Choose BMC and benefit from:

- fast, convenient online submission

- thorough peer review by experienced researchers in your field

- rapid publication on acceptance

- support for research data, including large and complex data types

- gold Open Access which fosters wider collaboration and increased citations

- maximum visibility for your research: over 100M website views per year

At BMC, research is always in progress.

Learn more biomedcentral.com/submissions 